\title{
Can we model observed soil carbon changes from a dense inventory? A case study over England and Wales using three versions of the ORCHIDEE ecosystem model (AR5, AR5-PRIM and O-CN)
}

\author{
B. Guenet ${ }^{1,2}$, F. E. Moyano ${ }^{3}$, N. Vuichard ${ }^{1}$, G. J. D. Kirk ${ }^{4}$, P. H. Bellamy ${ }^{4}$, S. Zaehle ${ }^{5}$, and P. Ciais ${ }^{1}$ \\ ${ }^{1}$ Unité Mixte de Recherche CEA-CNRS-UVSQ, UMR8212, Laboratoire des Sciences du Climat et de l'Environnement, \\ 91191 Gif-sur-Yvette, France \\ ${ }^{2}$ Department of Biology, Research Group of Plant and Vegetation Ecology, University of Antwerp, Universiteitsplein 1, \\ 2610 Wilrijk, Belgium \\ ${ }^{3}$ CNRS-BIOEMCO, UMR 7618, Bâtiment EGER, 78850 Thiverval Grignon, France \\ ${ }^{4}$ National Soil Resources Institute, Department of Environmental Science and Technology, Cranfield University, \\ Cranfield, UK \\ ${ }^{5}$ Max Planck Institute for Biogeochemistry, Department for Biogeochemical Systems, Hans-Knöll-Str. 10, \\ 07745 Jena, Germany
}

Correspondence to: B. Guenet (bertrand.guenet@1sce.ipsl.fr)

Received: 7 June 2013 - Published in Geosci. Model Dev. Discuss.: 12 July 2013

Revised: 14 November 2013 - Accepted: 18 November 2013 - Published: 19 December 2013

\begin{abstract}
A widespread decrease of the topsoil carbon content was observed over England and Wales during the period 1978-2003 in the National Soil Inventory (NSI), amounting to a carbon loss of $4.44 \mathrm{Tg} \mathrm{yr}^{-1}$ over $141550 \mathrm{~km}^{2}$. Subsequent modelling studies have shown that changes in temperature and precipitation could only account for a small part of the observed decrease, and therefore that changes in land use and management and resulting changes in heterotrophic respiration or net primary productivity were the main causes. So far, all the models used to reproduce the NSI data have not accounted for plant-soil interactions and have only been soil carbon models with carbon inputs forced by data. Here, we use three different versions of a process-based coupled soil-vegetation model called ORCHIDEE (Organizing Carbon and Hydrology in Dynamic Ecosystems), in order to separate the effect of trends in soil carbon input from soil carbon mineralization induced by climate trends over 1978-2003. The first version of the model (ORCHIDEE-AR5), used for IPCC-AR5 CMIP5 Earth System simulations, is based on three soil carbon pools defined with first-order decomposition kinetics, as in the CENTURY model. The second version (ORCHIDEE-AR5-PRIM) built for this study includes a relationship between litter carbon and decomposition rates,
\end{abstract}

to reproduce a priming effect on decomposition. The last version $(\mathrm{O}-\mathrm{CN})$ takes into account N-related processes. Soil carbon decomposition in O-CN is based on CENTURY, but adds $\mathrm{N}$ limitations on litter decomposition. We performed regional gridded simulations with these three versions of the ORCHIDEE model over England and Wales. None of the three model versions was able to reproduce the observed NSI soil carbon trend. This suggests either that climate change is not the main driver for observed soil carbon losses or that the ORCHIDEE model even with priming or $\mathrm{N}$ effects on decomposition lacks the basic mechanisms to explain soil carbon change in response to climate, which would raise a caution flag about the ability of this type of model to project soil carbon changes in response to future warming. A third possible explanation could be that the NSI measurements made on the topsoil are not representative of the total soil carbon losses integrated over the entire soil depth, and thus cannot be compared with the model output. 


\section{Introduction}

Soils contain between $70 \%$ and $80 \%$ of the organic carbon (C) storage in terrestrial ecosystems (MEA, 2005). The amount of $\mathrm{C}$ stored in soils is at least two times the amount in the atmosphere and three times the amount in plant biomass globally. Even changes of a few percent in the soil carbon reservoir can thus lead to significant changes in atmospheric $\mathrm{CO}_{2}$ relative to those released by fossil fuel combustion (Rustad et al., 2000). Global soil carbon storage is currently estimated to increase (Schmidt et al., 2011), but the storage capacity of soils appears to be limited (Six et al., 2002; Jastrow et al., 2005; Hungate et al., 2009), in particular because increased input to the soil feeds back to increased decomposition.

Based on 5662 in situ measurements from the National Soil Inventory (NSI) of England and Wales, collected on a $5 \mathrm{~km}$ grid, Bellamy et al. (2005) found that the soil organic carbon (SOC) content over $0-15 \mathrm{~cm}$ depth decreased over England and Wales during the period 1978-2003. They hypothesized that this decrease might in part be due to climate change because the observed decrease occurred across all types of land use across the two countries. Subsequently different modelling approaches have been used to try to reproduce this trend and understand its drivers: Smith et al. (2007) with the RothC model, Kirk and Bellamy (2010) with a single-pool model calibrated with NSI measurements, and Foereid et al. (2012) with DAYCENT. All these studies concluded that, as modelled, changes in temperature and precipitation were not the most important driver of the negative trends of SOC measured over England and Wales. If the results from these models are correct, they indicate that changes in land use and management must be the main driving factors of the observed large-scale decrease. Yet, RothC and DAYCENT are models of soil carbon decomposition, not ecosystem models, and as such do not represent the indirect effect of trends in climate and $\mathrm{CO}_{2}$ fertilization on plant productivity, and thereby on carbon input to the soil, and their feedback on SOC storage. In addition, these models did not account for soil carbon-nitrogen $(\mathrm{C}-\mathrm{N})$ interactions. Net primary production (NPP) modifications due to harvest, starvation, fire or $\mathrm{CO}_{2}$ increase altogether affect SOC dynamics. For instance, at experimental sites under elevated $\mathrm{CO}_{2}$, increased NPP was found to increase SOC mineralization (Jastrow et al., 2005), and the availability of $\mathrm{N}$ seemed to control this response (Hungate et al., 2009). Nitrogen mechanisms control both NPP and mineralization (Rustad et al., 2001; Moorhead and Sinsabaugh; 2006; Deng et al., 2010). Moreover, by providing energy to decomposers through the exudation of labile compounds, plants may stimulate the soil organic matter mineralization to obtain $\mathrm{N}$ stored within the soil organic matter by providing the energy to decomposers through exudation of labile compounds (Philips et al., 2012). If more $\mathrm{N}$ is available due to an increase of $\mathrm{N}$ deposition or an increase in soil $\mathrm{N}$ storage from increasing fertilizer applications, plants can reduce $\mathrm{C}$ allocation to roots, and therefore reduce soil C inputs (Högberg et al., 2010). Because $\mathrm{CO}_{2}$ increased by $75 \mathrm{ppm}$ and temperature increased by $0.5^{\circ} \mathrm{C}$ over England and Wales during the NSI sampling period 1978-2003, an increase of NPP is likely to have occurred over this period and to have affected SOC trends. There is indeed evidence for increase in photosynthetic activity from satellite observations (greenness index such as normalized difference vegetation index, NDVI) over the UK and the rest of Europe during the past $30 \mathrm{yr}$ (Julien et al., 2006; Zhou et al., 2001). A positive trend of NPP would likely affect the inputs of $\mathrm{C}$ into soils. Apart from a direct addition to soil C stocks, fresh C inputs from increased NPP also have the potential to prime the decomposition process, which will act to reduce soil C stocks and thus partially offset the gains from increased NPP. Soil C priming is defined as a change in "native" SOC mineralization rate due to the input of "fresh" organic C (FOC) from plant material (Kuzyakov et al., 2000). This change is mostly positive, slowing down the increase in SOC as more litter is added or even producing a net SOC decrease as observed in one controlled experiment (Fontaine et al., 2004). Priming is expected to induce an extra mineralization of existing SOC (Blagodatskaya et al., 2007; Fontaine et al., 2007; Guenet et al., 2012) and could thus explain the observed SOC decrease at the NSI sites.

The goal of this study is to use the NSI data of Bellamy et al. (2005) to evaluate the performance of an ecosystem model that accounts for three key biogeochemical processes considered to be potential drivers of SOC changes (Friedlingstein et al., 2006; Jones et al., 2003; Eglin et al., 2010):

1. Climate dependency of SOC decomposition rates and NPP, i.e. the response to temperature and moisture changes, with associated changes in soil $\mathrm{C}$ inputs and outputs.

2. Priming effects that accelerate SOC decomposition in response to an NPP-driven change of FOC inputs into soils.

3. Effects of $\mathrm{N}$ availability (through changes in deposition or fertilizer applications) that affect $\mathrm{C}$ allocation into roots and therefore the input of $\mathrm{C}$ into soils.

Note that land use change and erosion-related effects on SOC are not modelled explicitly in our approach. Their importance could be inferred as a residual between observed SOC trends and modelled trends, which are here driven only by biogeochemical processes.

We incorporated the three following biogeochemical processes into different versions of the process-based ORCHIDEE (Organizing Carbon and Hydrology in Dynamic Ecosystems) ecosystem model: climate and $\mathrm{CO}_{2}$ effects on NPP and respiration, priming of decomposition by increased $\mathrm{NPP}$, and indirect effects of $\mathrm{N}$ on decomposition through allocation. The first version (ORCHIDEE-AR5) is the one integrated for global coupled carbon-climate simulations of 
the Fifth Assessment Report (AR5) of the Intergovernmental Panel on Climate Change (IPCC). It contains the effect of temperature and soil moisture on decomposition. The second version, ORCHIDEE-AR5-PRIM, additionally includes a priming effect. The third version, called ORCHIDEECarbon-Nitrogen (O-CN; Zaehle and Friend, 2010), also stems from ORCHIDEE-AR5 but adds $\mathrm{N}-\mathrm{C}$ interactions that modify NPP, allocation and litter mineralization.

\section{Materials and methods}

\subsection{The data}

The NSI soil data and the vegetation types on each site were obtained from Foereid et al. (2012), who calculated the C stock from the soil survey of England and Wales held in the LandIS database (www.landis.org.uk; Proctor et al., 1998). We used only points where land use corresponded to arable land or grassland with no change during the period of observations. The LandIS database provides soil $\mathrm{C}$ concentration (relative to soil mass), whereas our model outputs are total C per unit area $\left(\mathrm{kg} \mathrm{m}^{-2}\right)$. Therefore, to compare observations with model results, stocks on each site were calculated by Foereid et al. (2012) as follows:

Stock $=\rho \times C \times h$,

where $\rho$ is the soil bulk density $\left(\mathrm{kg} \mathrm{m}^{-3}\right), C$ is the measured $\mathrm{C}$ concentration $\left(\mathrm{kg} \mathrm{C} \mathrm{kg}^{-1}\right.$ soil) and $h$ is the height of the layer sampled (m). The ORCHIDEE soil module has a fixed topsoil depth of $20 \mathrm{~cm}$, so we used $h=0.2 \mathrm{~m}$. The C concentration was measured in the $0-15 \mathrm{~cm}$ horizon (Bellamy et al., 2005). We therefore assumed that the concentration of $\mathrm{C}$ in the $15-20 \mathrm{~cm}$ horizon was the same as the concentration measured between 0 and $15 \mathrm{~cm}$. We acknowledge that this assumption may induce an overestimation of the stock since concentrations typically decrease with depth. We only consider sites (415 in total) where bulk density data are available. For these sites the first measurements were done in 1980 and the second one around 1995. Therefore, we considered this period in the entire study instead of the 1978-2003 period used by Bellamy et al. (2005).

For the period 1992-2002, we used a satellite-derived leaf area index (LAI) dataset created by Piao et al. (2006). It was based on the relationship between LAI and the NDVI established by Myneni et al. (1997) and calculated using the NDVI products defined by the global inventory monitoring and modelling studies group (GIMMS) derived from the NOAA/AVHRR (National Oceanic and Atmospheric Administration's Advanced Very High Resolution Radiometer) series satellites (NOAA 7, 9, 11 and 14). We extracted these $8 \mathrm{~km}^{2}$ biweekly satellite LAI data over England and Wales for the period 1982-2002 and calculated LAI long-term linear trends. For the latter we used a filtering model (lowpass time domain filtered residuals from the periodic curve;
Thoning et al., 1989) designed to separate a linear trend, a periodic annual cycle (harmonics), and inter-annual variations from raw data using low-pass time domain filtered residuals from the periodic curve. We applied the same model to extract linear trends from the LAI outputs of the models. We used such data as a surrogate to estimate how the models were able to reproduce the NPP trends during the period observed.

\subsection{The models}

\subsubsection{ORCHIDEE-AR5}

ORCHIDEE-AR5 is a spatially explicit process-based model that calculates the fluxes of $\mathrm{CO}_{2}, \mathrm{H}_{2} \mathrm{O}$, and heat exchanged between the land surface and the atmosphere on a half-hourly basis, and the variations of water and carbon pools on a daily basis. It is based on the coupling of three different models: one describes exchanges of energy and water between the atmosphere and the biosphere as well as the soil water budget (SVAT SECHIBA; Ducoudré et al., 1993; de Rosnay and Polcher, 1998). Another, derived from the dynamic global vegetation model LPJ (Lund-Potsdam-Jena) (Sitch et al., 2003), deals with vegetation dynamics (fire, sapling establishment, light competition, tree mortality, and climatic criteria for the introduction or elimination of plant functional types). The last calculates processes related to phenology and carbon dynamics of the terrestrial biosphere (STOMATE, Saclay Toulouse Orsay Model for the Analysis of Terrestrial Ecosystems).

In ORCHIDEE-AR5 and in the derived models, the vegetation is described using 12 plant functional types (PFT). Each PFT follows the same set of governing equations but takes different parameter values, except for the leafy season onset and offset, which are defined by PFT-specific equations (Krinner et al., 2005). One PFT represents all the grasses with $\mathrm{C} 3$ photosynthesis and another represents all the crops with $\mathrm{C} 3$ photosynthesis. Grassland management and crop rotation are not represented. For cropland sites, a fraction of $45 \%$ of the above-ground plant biomass is exported (harvested) each year and thus does not return to the soil.

The simulation of SOC is based on the equations of the CENTURY model (Parton et al., 1988). SOC is divided into three pools, which differ in their turnover rates. Litter is divided into a metabolic and structural pool, differing in their turnover rates, and subsequently separated into above-ground and below-ground inputs, resulting in four litter pools. Pool mineralization is described by first-order kinetics. Furthermore, three scalars modify the turnover rate of each pool to represent the effect of soil temperature, moisture and texture on decomposition. To represent tillage, soil decomposition is increased by $20 \%$ in the presence of $\mathrm{C} 3$ crops. The effect of $\mathrm{pH}$ on decomposition is not represented in the model. The model has been evaluated in several contrasted situations 
(Krinner et al., 2005; Ciais et al., 2005; Santaren et al., 2007; Piao et al., 2008).

\subsubsection{ORCHIDEE-AR5-PRIM}

To represent priming in this study, we keep the CENTURY carbon pools but replaced the decomposition equations of CENTURY by the ones developed by Guenet et al. (2013) using the formulation of Wutzler and Reichstein (2008) for priming:

$$
\frac{\partial \mathrm{SOC}}{\partial t}=I-k_{\mathrm{SOC}} \times \mathrm{SOC} \times\left(1-e^{-c \times \mathrm{FOC}}\right),
$$

where $I$ is the input of $\mathrm{C}$ into the pool considered, $k_{\mathrm{SOC}}$ is a SOC decomposition rate, and $c$ a parameter controlling the interaction of the FOC carbon pool with the SOC mineralization. Here FOC represents all the labile carbon in the pool considered. This means that for the active carbon pool, FOC is the litter; but for the slow carbon pool, FOC is the litter and the active pool; and finally, for the passive carbon pool, FOC is the litter, the active and the slow carbon pools. Ghee et al. (2013) recently suggested that priming was not sensitive to temperature; we therefore decided not to define a temperature dependency on the parameter $c$. In the original equations from Wutzler and Reichstein (2008) the SOC mineralization was described as

$$
\frac{\partial \mathrm{SOC}}{\partial t}=I-k_{\mathrm{SOC}} \times \mathrm{SOC} \times\left(1-e^{-c \times \mathrm{MB}}\right),
$$

where MB is the microbial biomass. Unlike Wutzler and Reichstein (2008), we do not explicitly represent the MB term and rather assume a linear relationship between FOC and microbial biomass. This approach to include priming in a generic SOC decomposition model assumes implicitly that MB is always in equilibrium with FOC. Consequently, we can use a direct relationship between SOC mineralization and FOC to represent priming. The parameters of Eq. (2) were adjusted to values resulting in similar steady-state total SOC values for both versions of ORCHIDEE-AR5 and ORCHIDEE-AR5-PRIM.

\subsubsection{O-CN}

O-CN (Zaehle and Friend, 2010) is an enhanced version of ORCHIDEE with an explicit representation of $\mathrm{C}-\mathrm{N}$ interactions. The structural differences between $\mathrm{O}-\mathrm{CN}$ and ORCHIDEE-AR5 are (i) a dynamic representation of $\mathrm{N}$ flows within plant biomass; (ii) the incorporation of a limiting factor for litter decomposition, if $\mathrm{N}$ is not available; (iii) the consideration of the effects of N input on NPP, allocation and decomposition ( $\mathrm{N}$ input denoting here $\mathrm{N}$ deposition, fertilization and biological fixation); and (iv) the emissions of gaseous $\mathrm{N}$ compounds from ecosystems. $\mathrm{O}-\mathrm{CN}$ further differs from ORCHIDEE-AR5 in the allocation of NPP products, changed from Friedlingstein et al. (1999) to a scheme based on allometric constraints (Shinozaki et al., 1964; Zaehle et al., 2006). The seasonal phenology was further modified, compared to ORCHIDEE-AR5, by considering the dynamics of labile and reserve storage pools, while the controlling climatic factors for the start and the end of the growing season were not changed.

\subsubsection{Code availability}

For ORCHIDEE-AR5, the code mainly comes from Krinner et al. (2005). The version used here corresponds to the 1.9.5.2 version. Since 2005, several modifications have been done, like an improved representation of albedo (F. Hourdin et al., personal communication, 2006) and the addition of a routing scheme which controls the flux of water from land surface to the ocean (Ngo-Duc et al., 2007). Moreover some options were added, such as a representation of a more complex hydrological scheme for the soil based on De Rosnay (1999) and presented in d'Orgeval et al. (2008) or a better description of the dynamic of vegetation (N. Viovy et al., personal communication, 2006). However, in this study we used the previous soil hydrological scheme described in Krinner et al. (2005) and, since we did not represent land use, the dynamic of vegetation is not used here. Furthermore, since 2005 the code has been parallelized. The code can be found at http://forge.ipsl.jussieu.fr/ orchidee/browser/tags/ORCHIDEE_1_9_5_2 and a detailed documentation can be found at http://forge.ipsl.jussieu.fr/ orchidee/wiki/Documentation.

ORCHIDEE-AR5-PRIM is derived from ORCHIDEEAR5 with the modifications presented in the Sect. 2.2.2. This study is the first to use this version and must be considered as the code documentation. Any request to use the code must be directly addressed to the corresponding author.

$\mathrm{O}-\mathrm{CN}$ was described in detail in Zaehle and Friend (2010). The version used here has been slightly modified to ensure portability of code. Any request concerning O-CN must be directly addressed to the corresponding author.

\subsection{The simulation experiments set over England and Wales}

Simulations over the England and Wales territory were performed with the three versions of the ORCHIDEE model at $0.5^{\circ} \times 0.5^{\circ}$ spatial resolution. We used the soil parameters (clay, silt and sand fractions) from Zobler (1986) and the vegetation distribution from Hurtt et al. (2011) corresponding to year 1975. Land use changes were not taken into account, and the land cover map does not change during the simulations. The monthly climate data to drive the different model versions were obtained from the Climate Research Unit (CRU) at a spatial resolution of $0.5^{\circ} \times 0.5^{\circ}$ (Mitchell et al., 2004) and interpolated in time to a half-hourly time step (the time step of the ORCHIDEE model) using meteorological parameters obtained from a Richardson-type weather 
generator (Richardson and Wright, 1984; Friend, 1998; A. Foley, personal communication, 1999). For O-CN, we used $\mathrm{N}$ deposition, $\mathrm{N}$ fixation and $\mathrm{N}$ fertilization maps from Cleveland et al. (1999), Galloway et al. (2004) and Dentener et al. (2006) at a spatial resolution of $0.5^{\circ} \times 0.5^{\circ}$. To reach equilibrium we ran ORCHIDEE-AR5, ORCHIDEE-AR5PRIM and O-CN using the first decade of the climate forcing (1901-1909) repeated in a loop, and the preindustrial value of atmospheric $\mathrm{CO}_{2}$. For O-CN, $\mathrm{N}$ deposition, fixation and fertilization were also fixed to preindustrial values during this spin-up phase. We considered that SOC equilibrium was reached when the simulated relative SOC stock change is less than $0.001 \%$ per year. Once SOC equilibrium was reached in each grid point, we performed transient simulations over the 20th century driven by climate, $\mathrm{CO}_{2}$ and $\mathrm{N}$ deposition and fertilization data. To compare observations and model results, we extracted the soil $\mathrm{C}$ stocks in the pixel corresponding to the coordinates of each site during the NSI sampling period 1978-2003. Finally, to calculate the trend for each pixel with the models we used the same methods used for the data:

Trend $=\frac{\mathrm{SOC}_{T f}-\mathrm{SOC}_{T i}}{\Delta t}$,

where $\mathrm{SOC}_{T f}$ is the SOC stocks in $1995, \mathrm{SOC}_{T i}$ is the SOC stocks in 1980 and $\Delta t$ the length of the time period.

\section{Results and discussion}

\subsection{Soil C stock in 1980}

For the grid points corresponding to the soil survey sites, the average modelled SOC stocks during the year 1980 are slightly overestimated by ORCHIDEE-AR5 and ORCHIDEE-AR-5-PRIM $\left(14.76 \mathrm{~kg} \mathrm{~m}^{-2}\right.$ and $16.25 \mathrm{~kg} \mathrm{~m}^{-2}$, for the ORCHIDEE-AR5 and ORCHIDEE-AR5-PRIM model versions, respectively) compared to the NSI measurements $\left(12.83 \pm 1.6 \mathrm{~kg} \mathrm{~m}^{-2}\right.$, mean $\pm 95 \%$ confidence interval). This result suggests that using ORCHIDEE-AR5 and ORCHIDEE-AR5-PRIM overestimated the NPP or underestimated the turnover rate. For ORCHIDEE-AR5, Todd-Brown et al. (2013) showed that both happen when ORCHIDEE-AR5 is used as the land surface module of the Earth system model IPSL-CM5. On the other hand, O-CN underestimates the initial $\mathrm{C}$ stocks $\left(5.38 \mathrm{~kg} \mathrm{~m}^{-2}\right)$. This may be due to an overestimation of N limitations on NPP affecting the increase of carbon input to the soils during the 20th century. The underestimation by $\mathrm{O}-\mathrm{CN}$ could also be due to an underestimated representation of the $\mathrm{N}$ limitation on decomposition, leading to a too-rapid decomposition. However, all model versions largely underestimated the spatial variance observed between sites (Fig. 1). This may be due to the generic representation of SOC decomposition in the three models despite the additional mechanisms incorporated in ORCHIDEE-AR5-PRIM and in O-CN compared to

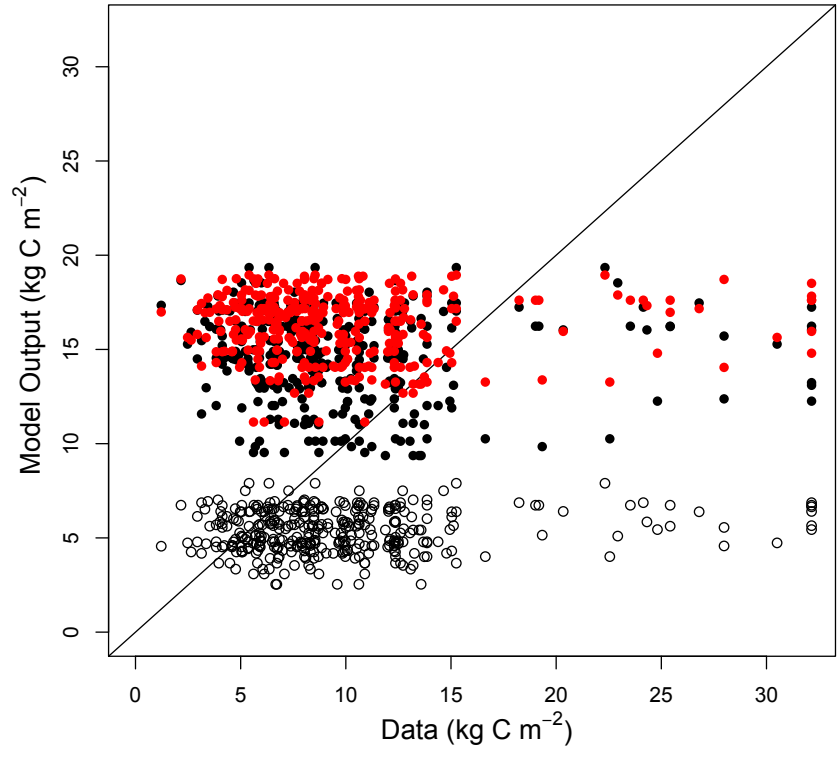

Fig. 1. Scatterplot of the C stock in 1980 calculated by ORCHIDEEAR5 (black circles), ORCHIDEE-AR5-PRIM (red circles) and O$\mathrm{CN}$ (open circles) versus the observed $\mathrm{C}$ stock.

ORCHIDEE-AR5 and/or to the lack of site-specific data on vegetation structure, rooting depth, soil depth, thermic conductivity and water holding capacities to reproduce NPP and soil $\mathrm{C}$ input at the NSI sites. Further, processes known as drivers of steady-state SOC values in soils (von Lützow et al., 2006) are not represented in ORCHIDEE-AR5, such as the stabilization of organic matter on mineral surfaces (except clay) and metal ions, or the effect of former land use and of soil fauna (e.g. earthworms) on SOC mineralization and stabilization (von Lützow et al., 2006; Lavelle, 1997; Schmidt et al., 2011). Not having those mechanisms may induce important changes at the local level that result in over- or underestimations of $\mathrm{C}$ stocks by the model and a general underestimation of SOC variability. Therefore, we can conclude that ORCHIDEE-AR5 and its derived models are capable of reproducing a realistic mean SOC over England and Wales as a whole but not specific SOC values at the site scale.

\subsection{Soil C stock changes}

From the regional simulation over England and Wales, in the ORCHIDEE-AR5 simulations, we diagnosed a mean increase of $8.1 \pm 0.3 \mathrm{~g} \mathrm{C} \mathrm{m}^{-2} \mathrm{yr}^{-1}$ of SOC stock (uncertainty from spatial variability, $p<0.001$ Mann-Kendall test) over England and Wales during the period 1980 1995 (Table 1). Oppositely, the NSI data have a trend of $-31.4 \mathrm{~g} \mathrm{C} \mathrm{m}^{-2} \mathrm{yr}^{-1}$. The modelled trends can be separated according to land use. The regional simulations produce an average trend of $7.7 \pm 2.8 \mathrm{~g} \mathrm{C} \mathrm{m}^{-2} \mathrm{yr}^{-1}$ for arable soils and of $8.4 \pm 2.7 \mathrm{~g} \mathrm{C} \mathrm{m}^{-2} \mathrm{yr}^{-1}$ for grassland soils, these being very similar. Finally, the ORCHIDEE-AR5 model simulated 
an increase rate of $\mathrm{C}$ stock of $1.8 \pm 3.0 \mathrm{~g} \mathrm{C} \mathrm{m}^{-2} \mathrm{yr}^{-1}$ for deciduous forest and of $0.3 \pm 0.9 \mathrm{~g} \mathrm{C} \mathrm{m}^{-2} \mathrm{yr}^{-1}$ for evergreen forest.

ORCHIDEE-AR5 predicts a general increase of the SOC when driven by climate and $\mathrm{CO}_{2}$ (Table 1), oppositely to the NSI measurements, but in accordance with the model equations, and from what it is generally expected from the increase of NPP in temperate ecosystems, induced by elevated $\mathrm{CO}_{2}$ and temperature, and the resulting increase of $\mathrm{C}$ inputs into soils, causing an increase in SOC storage. The increase of primary production is relatively close to what is observed when using LAI as a proxy (Table 1) but a little bit overestimated when comparing the biomass increase of crops in the model $(+16 \%)$ to yield increases measured over the period 1976-2002 (12\% for wheat and 7\% for barley, data from http://archive.defra.gov.uk/evidence/statistics/ foodfarm/enviro/observatory/indicators/b/b11_data.htm).

However, it must be noted that the increase of primary productivity in ORCHIDEE is only due to climate and $\mathrm{CO}_{2}$ modifications, whereas the increase of crop yields is likely the results of changes not only in climate and $\mathrm{CO}_{2}$ but also in agricultural practices. In ORCHIDEE-AR5, an increased input of $\mathrm{C}$ into soils dominates over the increase of SOC mineralization with higher temperatures (Davidson and Janssens, 2006; Conant et al., 2011), suggesting that the combined effects of climate and $\mathrm{CO}_{2}$ on the balance between SOC decomposition and primary production result in a net increase of SOC. In summary, climate effects alone could not explain the observed SOC decrease.

An increase of litter input to the soil is predicted both by ORCHIDEE-AR5 and ORCHIDEE-AR5-PRIM $\left(4.4 \pm 0.6 \mathrm{~g} \mathrm{C} \mathrm{m}^{-2} \mathrm{yr}^{-1}\right)$, which have the same plant-related modules and $\mathrm{C}$ input fluxes (Table 1). The ORCHIDEEAR5-PRIM model predicts a general decrease of SOC stocks during the 20th century (Fig. 2) because of its specific representation of a priming effect driven by fresh litter input. However, over the period 1980-1995 corresponding to the two sampling events of the sites considered here, the SOC stock slightly increases but is close to zero in the simulation of ORCHIDEE-AR5-PRIM $\left(1.7 \pm 0.2 \mathrm{~g} \mathrm{C} \mathrm{m}^{-2} \mathrm{yr}^{-1}\right.$, $p<0.001$ Mann-Kendall test) compared to $1 \%$ decrease (Table 1) in the NSI observations $\left(-31.4 \mathrm{~g} \mathrm{C} \mathrm{m}^{-2} \mathrm{yr}^{-1}\right)$. Thus, in the configuration used here, priming could not explain the observed negative SOC trend. However, this mechanism has the potential to reverse the trend of SOC compared to the standard ORCHIDEE-AR5 version. Averaged during the entire 20th century, priming produces in the model a negative SOC trend comparable to the one measured by NSI during 1980-1995. Thus if the NPP increase during the first half of the 20th century is overestimated by ORCHIDEE (e.g. because of crop species with lower yields, less fertilizers, $\mathrm{N}$ limitations in pasture not being included), then priming could explain the observed SOC decrease during 1980-1995.

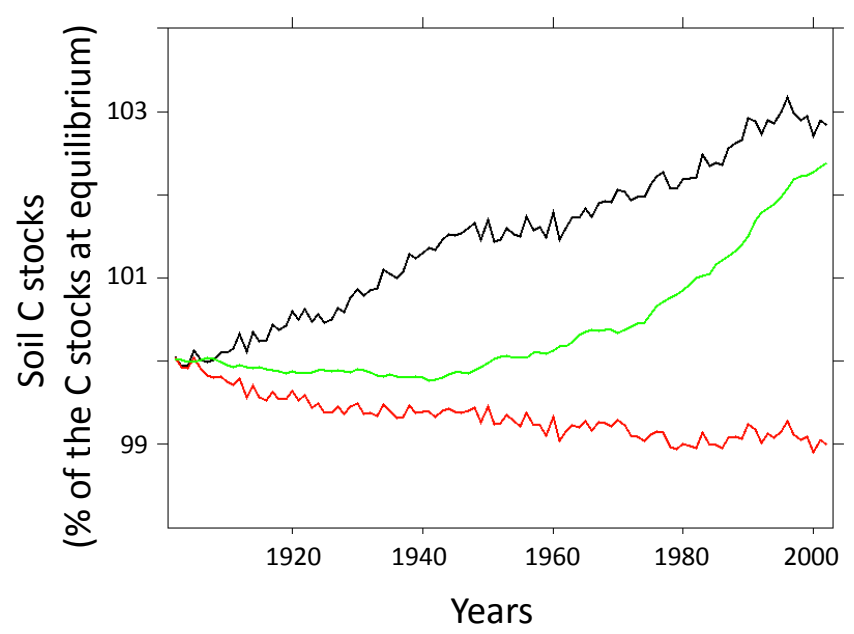

Fig. 2. $\mathrm{C}$ stock evolution over the 20th century normalized by the $\mathrm{C}$ stock at equilibrium (annual values) for ORCHIDEE-AR5 (black), ORCHIDEE-AR5-PRIM (red) and for O-CN (green). At equilibrium, soil $\mathrm{C}$ stocks corresponded to $13.9 \mathrm{~kg} \mathrm{~m}^{-2}, 16.1 \mathrm{~kg} \mathrm{~m}^{-2}$ and $5.1 \mathrm{~kg} \mathrm{~m}^{-2}$ for ORCHIDEE-AR5, ORCHIDEE-AR5-PRIM and for $\mathrm{O}-\mathrm{CN}$, respectively.

ORCHIDEE-AR5-PRIM is a first and coarse attempt to represent priming. It is interesting to note that a simple change in the model structure for decomposition is able to reverse the sign of SOC trends, given the same litter input forcing. Thus, priming is a very sensitive mechanism controlling SOC trends. Without priming, the model predicts that soil $\mathrm{C}$ storage increases over England and Wales by $0.4 \mathrm{~kg} \mathrm{C} \mathrm{m}^{-2}$ ( $2.6 \%$ of initial stocks) over the 20 th century while it decreases by $0.15 \mathrm{~kg} \mathrm{C} \mathrm{m}^{-2}$ with priming $(0.9 \%$ of initial stocks). Further work is needed to evaluate the ORCHIDEE-AR5-PRIM model against SOC measurements. Priming has important consequences for $\mathrm{C}$ budget estimations and for the study of carbon-climate feedbacks at local to regional scale. For instance, our choice of representation of priming effects in a coupled carbon-climate model should increase SOC decomposition, and cause a positive climate feedback.

In the O-CN regional simulations, soil C stocks in England and Whales show a significant increase during the studied period by a rate of $4.2 \pm 0.2 \mathrm{~g} \mathrm{C} \mathrm{m}^{-2} \mathrm{yr}^{-1}(p<0.001$ Mann-Kendall test, Table 1). As in ORCHIDEE-AR5, this is mainly controlled by increased C input from NPP. The trend of biomass in O-CN parallels the trends of $\mathrm{N}$ deposition and fertilization (Fig. 3). A general increase of biomass is modelled during the 20th century, but two steps could be observed following the dynamics of $\mathrm{N}$ deposition and fertilization: a slow increase before the 1950s and a faster increase after that decade. Finally, an increase of $\mathrm{N}$ inputs (Fig. $3 \mathrm{~b}$ and c) did not reduce the $\mathrm{C}$ allocation to roots nor the associated $\mathrm{C}$ input into the soil in $\mathrm{O}-\mathrm{CN}$. These results suggest that $\mathrm{N}$-related processes from $\mathrm{O}-\mathrm{CN}$ are not responsible for the observed 
Table 1. Estimated rates observed and calculated by the different version of ORCHIDEE-AR5 from regional simulations over England and Wales (mean $\pm \mathrm{sd}$ ) for the period 1980-1995.

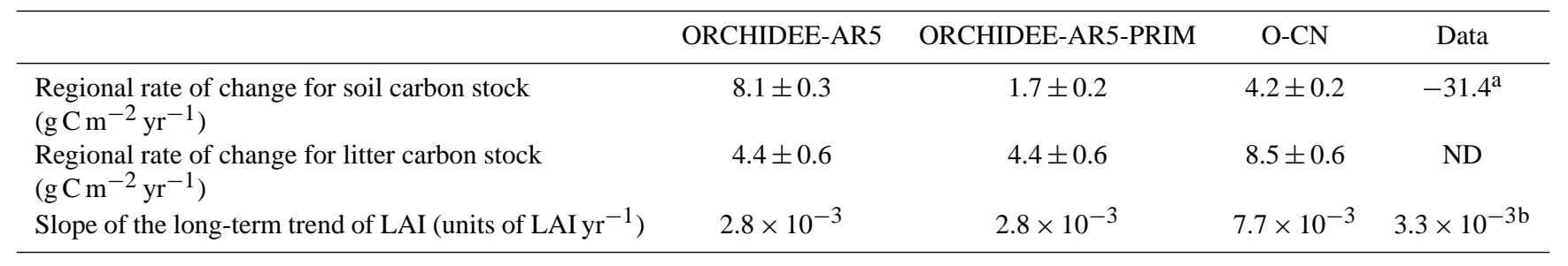

${ }^{a}$ Estimation from Bellamy et al. (2005). ${ }^{\mathrm{b}}$ Estimation calculated from satellite observation.

NSI SOC decrease. The slope of the long-term trend of LAI over the period 1980-1995 calculated by O-CN is higher than shown by the data $(+136 \%)$, whereas ORCHIDEE-AR5 and ORCHIDEE-AR5-PRIM both come closer to $(-17 \%)$, although lower than, the GIMMS satellite data $\left(3.3 \times 10^{-3}\right.$ units of LAI yr ${ }^{-1}$ ) (Table 1). The reason for the poorer performance by $\mathrm{O}-\mathrm{CN}$ is not clear. By definition, $\mathrm{O}-\mathrm{CN}$ is sensitive to modifications in $\mathrm{N}$ inputs, and the high level of deposition and fertilization observed in England and Wales induce an important increase of NPP in O-CN. But in reality this effect may be balanced by other limiting factors related to agricultural practice and soil quality ( $\mathrm{pH}$, other nutrients, physical properties). Since ORCHIDEE-AR5 and ORCHIDEEAR5-PRIM implicitly represent the effects of limiting nutrients (by empirical calibration) and are not sensitive to a modification of nutrient inputs, they may better reproduce the trends by averaging out the effects of $\mathrm{N}$ and other limiting factors. This comparison with satellite LAI trends suggests that ORCHIDEE-AR5 and ORCHIDEE-AR5-PRIM better reproduce the long-term trend of NPP than O-CN. Alternatively, mechanisms other than $\mathrm{CO}_{2}$ and climate - such as changes in cultivars, pasture management intensity and cultivation practice, which were not accounted for in any of the model versions - could also explain the satellite LAI trends, so that the good agreement of LAI trends with ORCHIDEEAR5 and ORCHIDEE-AR5-PRIM could reflect a compensation of biases.

Had we included priming effects in $\mathrm{O}-\mathrm{CN}$, the acceleration of soil C inputs to the soil in the 1950s shown by O-CN but not in the other versions could have induced a primingtriggered acceleration of SOC mineralization, but any conclusion about the quantification of such effect is not straightforward since there are several feedbacks between SOC mineralization increase, its associated release of $\mathrm{N}$ available for plants, the NPP and the C inputs into the soils. However, regarding the several processes controlling SOC dynamics as well as the numerous feedbacks between these processes, we do believe that a more mechanistic model is needed to reproduce the trend observed in the data.

\section{Conclusions}

In this study we used different versions of the same land surface model to test three mechanisms as drivers for the observed SOC changes in England and Wales: (i) responses to climate, (ii) priming effects, and (iii) $\mathrm{N}$ effects on the allocation of plant C. However, none of these could explain the observed decrease in $\mathrm{C}$ stocks. One of the main missing drivers within our simulations is the change in land use. Effects of land use change on soil $\mathrm{C}$ dynamics are not well understood (Post and Kwon, 2000), in particular the effect of past land use change. Its representation in models would therefore be based on very speculative assumptions and almost impossible to test. Several attempts have been done to reproduce the stock decrease over England and Wales with models lacking a representation of land use, and none of them were successful (Smith et al., 2007; Kirk and Bellamy, 2010; Foereid et al., 2012). Our study further did not investigate the effect of soil $\mathrm{C}$ priming and $\mathrm{N}$ effects on $\mathrm{C}$ allocation. Under the rather rigid set of hypotheses of this study, the simplest interpretation of our results is that recent changes in land use must be the most plausible explanation for the observed C stock decrease over the UK. At face value, our results also show that that the sign of simulated changes in $\mathrm{C}$ pools is sensitive to inclusion of priming. This suggests that priming cannot be ruled out as a driver of the observed UK soil carbon changes, but that interactions between priming and land management (e.g. tillage bringing in FOC to deeper horizons and accelerating the decomposition of slow carbon pools, or a temporal change of priming intensity due to a modification of the $\mathrm{C}$ allocation in roots in response to plant $\mathrm{N}$ demand) would need to be simulated more realistically to address this question. Moreover, the parameters of ORCHIDEE-AR5-PRIM were not well constrained since they were adjusted to obtain the same initial C stock at equilibrium as ORCHIDEEAR5. An optimization of these parameters against actual data may enable the ORCHIDEE-AR5-PRIM version to reproduce the trend observed over England and Wales. Nevertheless, Robinson and Sutherland (2002) showed that tillage intensity changed in the UK during the last $30 \mathrm{yr}$ of the 20th century and generally increased. Such changes might be responsible, at least partially, for the $\mathrm{C}$ stock decrease observed. 


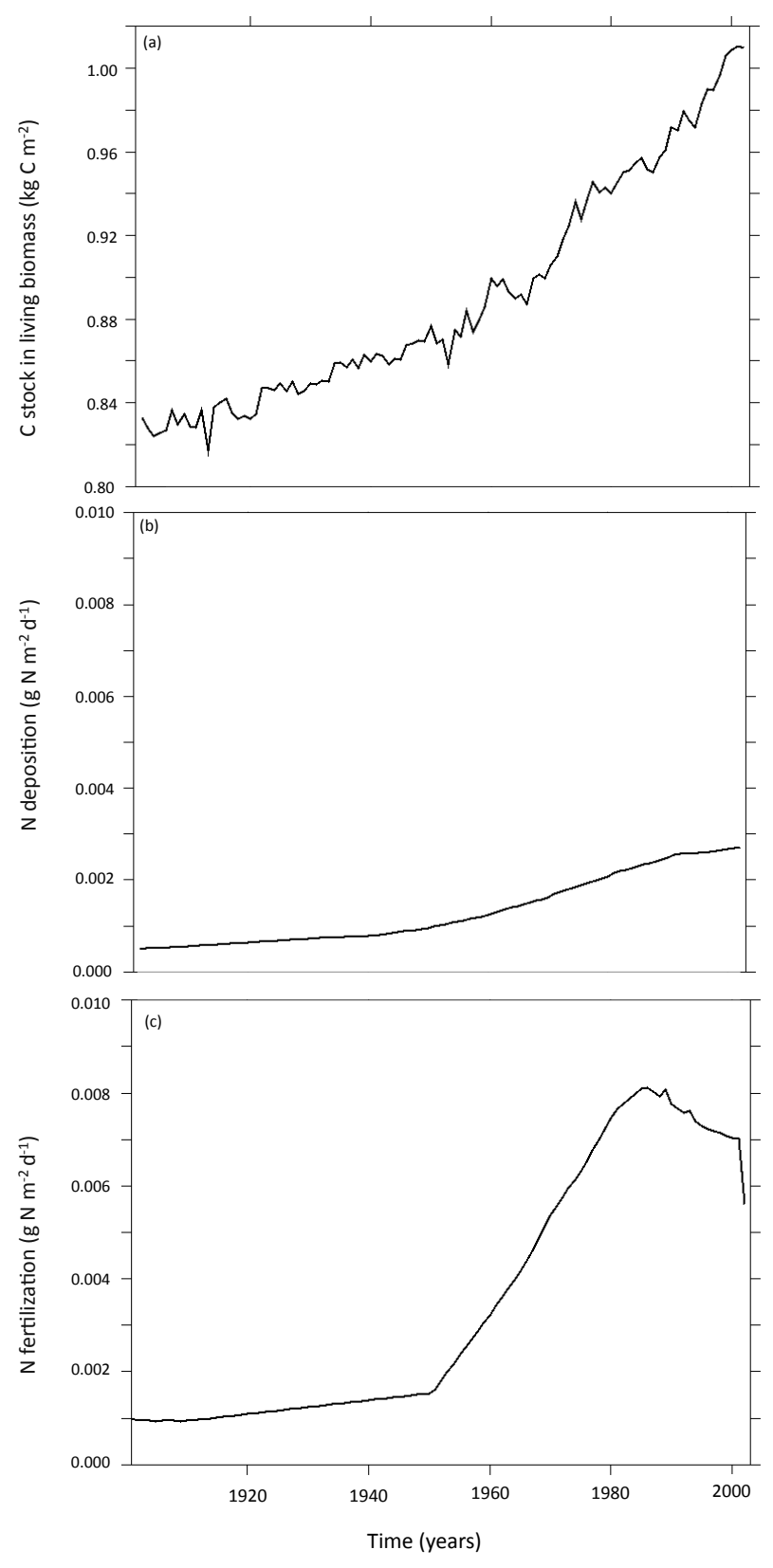

Fig. 3. Evolution over the 20th century of $\mathrm{C}$ stored in living biomass (a), of $\mathrm{N}$ deposition (b) and of $\mathrm{N}$ fertilization (c) in O-CN (annual values).

In addition, this study demonstrates the problem of predicting soil carbon stocks and stock changes as a general modelling issue. One limitation in this respect is the incomplete understanding of soil $\mathrm{C}$ dynamics, yet it is not surprising given the complexity of soil systems. For instance, the importance of priming effects tested here is still a matter of speculation, similar to many other mechanisms stabilizing soil carbon and determining the long-term evolution of carbon stocks under different soil types. Another main issue is the lack of information on the past conditions that lead to the current soil state for any given site. Without this information it is very difficult to understand why soil $\mathrm{C}$ is changing in one or the other direction, as we have shown in this study. The comparison of models to find the one that comes nearest to the observed trends is a way around this difficulty. But, as in our case, the results sometimes show that the major drivers are either unknown historical drivers (including drivers of priming changes) or mechanisms that are not yet well quantified and thus are not represented in our study. However, some of these mechanisms are already identified and should be incorporated in the next generation of land surface models. For example these mechanisms are the breakdown of aggregates due to tillage, erosion, export of dissolved organic carbon, etc. Finally, the interactions between these mechanisms, such as through priming and $\mathrm{N}$ dynamics, must be incorporated in soil carbon models to tackle the difficult science question of attributing observed soil C changes to "biotic", climatic or land use drivers.

Acknowledgements. The authors acknowledge financial support from the European FP7 project CARBO-Extreme and the GIS-Climat programme CARBOSOIL. Shilong Piao and Abdoul Khadre Traore are acknowledged for help with the GIMMS data.

Edited by: D. Lunt

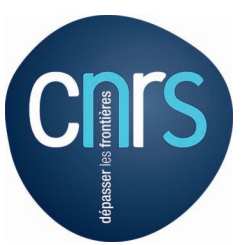

The publication of this article is financed by CNRS-INSU.

\section{References}

Bellamy, P. H., Loveland, P. J., Bradley, R. I., Lark, R. M., and Kirk, G. J. D.: Carbon losses from all soils across England and Wales 1978-2003, Nature, 437, 245-248, 2005.

Blagodatskaya, E. V., Blagodatsky, S. A., Anderson, T.-H., and Kuzyakov, Y.: Priming effects in chernozem induced by glucose and $\mathrm{N}$ in relation to microbial growth strategies, Appl. Soil Ecol., 37, 95-105, 2007.

Ciais, P., Reichstein, M., Viovy, N., Granier, A., Ogée, J., Allard, V., Aubinet, M., Buchmann, N., Bernhofer, C., Carrara, A., Chevallier, F., De Noblet, N., Friend, A. D., Friedlingstein, P., Grünwald, T., Heinesch, B., Keronen, P., Knohl, A., Krinner, G., Loustau, D., Manca, G., Matteucci, G., Miglietta, F., Ourcival, J. M., Papale, D., Pilegaard, K., Rambal, S., Seufert, G., Soussana, J. F., Sanz, M. J., Schulze, E. D., Vesala, T., and Valentini, R.: Europewide reduction in primary productivity caused by the heat and drought in 2003, Nature, 437, 529-533, 2005.

Cleveland, C. C., Townsend, A. R., Schimel, D. S., Fisher, H., Horwarth, R. W., Hedin, L. O., Perakis, S. S., Latty, E. F., Von Fischer, J. C., Esleroad, A., and Wasson, M. F.: Global patterns of 
terrestrial biological nitrogen (N2) fixation in natural systems, Global Biogeochem. Cy., 13, 623-645, 1999.

Conant, R. T., Ryan, M. G., Ågren, G. I., Birge, H. E., Davidson, E. A., Eliasson, P. E., Evans, S. E., Frey, S. D., Giardina, C. P., Hopkins, F. M., Hyvönen, R., Kirschbaum, M. U. F., Lavallee, J. M., Leifeld, J., Parton, W. J., Megan Steinweg, J., Wallenstein, M. D., Martin Wetterstedt, J. A., and Bradford, M. A.: Temperature and soil organic matter decomposition rates - synthesis of current knowledge and a way forward, Glob. Change Biol., 17, 3392-3404, 2011.

Davidson, E. A. and Janssens, I. A.: Temperature sensitivity of soil carbon decomposition and feedbacks to climate change, Nature, 440, 165-173, 2006.

Deng, Q., Zhou, G., Liu, J., Liu, S., Duan, H., and Zhang, D.: Responses of soil respiration to elevated carbon dioxide and nitrogen addition in young subtropical forest ecosystems in China, Biogeosciences, 7, 315-328, doi:10.5194/bg-7-315-2010, 2010.

Dentener, F., Drevet, J., Lamarque, J. F., Bey, I., Eickhout, B., Fiore, A. M., Hauglustaine, D., Horowitz, L. W., Krol, M., Kulshrestha, U. C., Lawrence, M., Galy-Lacaux, C., Rast, S., Shindell, D., Stevenson, D., Van Noije, T., Atherton, C., Bell, N., Bergman, D., Butler, T., Cofala, J., Collins, B., Doherty, R., Ellingsen, K., Galloway, J., Gauss, M., Montanaro, V., Müller, J. F., Pitari, G., Rodriguez, J., Sanderson, M., Solmon, F., Strahan, S., Schultz, M., Sudo, K., Szopa, S., and Wild, O.: Nitrogen and sulfur deposition on regional and global scales: A multimodel evaluation, Global Biogeochem. Cy., 20, GB4003, doi:10.1029/2005GB002672, 2006.

De Rosnay, P.: Representation of soil-vegetation-atmosphere interaction in the general circulation model of the Laboratoire de Météorologie Dynamique PhD. Thesis, Université de Paris VI, 1999.

De Rosnay, P. and Polcher, J.: Modelling root water uptake in a complex land surface scheme coupled to a GCM, Hydrol. Earth Syst. Sci., 2, 239-255, doi:10.5194/hess-2-239-1998, 1998.

d'Orgeval, T., Polcher, J., and de Rosnay, P.: Sensitivity of the West African hydrological cycle in ORCHIDEE to infiltration processes, Hydrol. Earth Syst. Sci., 12, 1387-1401, doi:10.5194/hess-12-1387-2008, 2008.

Ducoudré, N. I., Laval, K., and Perrier, A.: SECHIBA, a new set of parameterizations of the hydrologic exchanges at the landatmosphere interface within theLMDatmospheric general circulation model, J. Climate, 6, 248-273, 1993.

Eglin, T., Ciais, P., Piao, S., Barre, P., Bellassen, V., Cadule, P., Chenu, C., Gasser, T., Koven, C., Reichstein, M., and Smith, P.: Historical and future perspectives of global soil carbon response to climate and land-use changes, Tellus B, 62, 700-718, 2010.

Foereid, B., Bellamy, P. H., Holden, A., and Kirk, G. J. D.: On the initialization of soil carbon models and its effects on model predictions for England and Wales, European J. Soil Sci., 63, 32-41, 2012

Fontaine, S., Bardoux, G., Abbadie, L., and Mariotti, A.: Carbon input to soil may decrease soil carbon content, Ecol. Lett., 7, 314 320, 2004.

Fontaine, S., Barot, S., Barré, P., Bdioui, N., Mary, B., and Rumpel, C.: Stability of organic carbon in deep soil layers controlled by fresh carbon supply, Nature, 450, 277-280, 2007.
Friedlingstein, P., Joel, G., Field, C. B., and Fung, I. Y.: Toward an allocation scheme for the global terrestrial carbon models, Glob. Change Biol., 5, 795-817, 1999.

Friedlingstein, P., Cox, P., Betts, R., Bopp, L., Von Bloh, W. Brovkin, V., Cadule, P., Doney, S., Eby, M., Fung, I., Bala, G., John, J., Jones, C., Joos, F., Kato, T., Kawamiya, M., Knorr, W., Lindsay, K., Matthews, H. D., Raddatz, T., Rayner, P., Reick, C., Roeckner, E., Schnit- zler, K. G., Schnur, R., Strassmann, K.,Weaver, A. J., Yoshikawa, C., and Zeng, N.: Climate- carbon cycle feedback analysis: results from the C4MIP model intercomparison, J. Climate, 19, 3337-3353, 2006.

Friend, A. D.: Parameterisation of a global daily weather generator for terrestrial ecosystem and biogeochemical modelling, Ecol. Model., 109, 121-140, 1998.

Galloway, J. N., Dentener, F. J., Capone, D. G., Boyer, E. W., Howarth, R. W., Seitzinger, S. P., Asner, G. P., Cleveland, C. C., Green, P., Holland, E., Karl, D. M., Michaels, F., Porter, J. H., Townsend, R., and Vösömarty, C. J.: Nitrogen cycles: Past, present and future, Biogeochemistry, 70, 153-226, 2004.

Ghee, C., Neilson, R., Hallett, P. D., Robinson, D., and Paterson, E.: Priming of soil organic matter mineralisation is intrinsically insensitive to temperature, Soil Biol. Biochem., 66, 20-28, 2013.

Guenet, B., Juarez, S., Bardoux, G., Abbadie, L., and Chenu, C. Evidence that stable $\mathrm{C}$ is as vulnerable to priming effect as is more labile C in soil, Soil Biol. Biochem., 52, 43-48, 2012.

Guenet, B., Eglin, T., Vasilyeva, N., Peylin, P., Ciais, P., and Chenu, C.: The relative importance of decomposition and transport mechanisms in accounting for soil organic carbon profiles, Biogeosciences, 10, 2379-2392, doi:10.5194/bg-10-2379-2013, 2013.

Högberg, M. N., Briones, M. J. I., Keel, S. G., Metcalfe, D. B., Campbell, C., Midwood, A. J., Thornton, B., Hurry, V., Linder, S., Näsholm, T., and Högberg, P.: Quantification of effects of season and nitrogen supply on tree below-ground carbon transfer to ectomycorrhizal fungi and other soil organisms in a boreal pine forest, The New Phytologist, 187, 485-493, 2010.

Hungate, B., van Groenigen, K. J., Six, J., Jastrow, J. D., Luo, Y., de Graaff, M.-A., van Kessel, C., Osenberg, C., and Craig, W.: Assessing the effect of elevated carbon dioxide on soil carbon: a comparison of four meta-analyses, Glob. Change Biol., 15, 2020-2034, 2009

Hurtt, G. C., Chini, L. P., Frolking, S., Betts, R. A., Feddema, J., Fischer, G., Fisk, J. P., Hibbard, K., Houghton, R. A., Janetos, A., Jones, C. D., Kindermann, G., Kinoshita, T., Klein Goldewijk, K., Riahi, K., Shevliakova, E., Smith, S., Stehfest, E., Thomson, A., Thornton, P., Vuuren, D. P., and Wang, Y. P.: Harmonization of land-use scenarios for the period 1500-2100: 600 years of global gridded annual land-use transitions, wood harvest, and resulting secondary lands, Climatic Change, 109, 117-161, 2011.

Jastrow, J. D., Michael Miller, R., Matamala, R., Norby, R. J., Boutton, T. W., Rice, C. W., and Owensby, C. E.: Elevated atmospheric carbon dioxide increases soil carbon, Glob. Change Biol., 11, 2057-2064, 2005

Jones, C. D., Cox, P., and Huntingford, C.: Uncertainty in climatecarbon-cycle projections associated with the sensitivity of soil respiration to temperature, Tellus B, 55, 642-648, 2003.

Julien, Y., Sobrino, J. A., and Verhoef, W.: Changes in land surface temperatures and NDVI values over Europe between 1982 and 1999, Remote Sens. Environ., 103, 43-55, 2006. 
Kirk, G. J. D. and Bellamy, P. H.: Analysis of changes in organic carbon in mineral soils across England and Wales using a simple single-pool model, European J. Soil Sci., 61, 406-411, 2010.

Krinner, G., Viovy, N., de Noblet-Ducoudré, N., Ogée, J., Polcher, J., Friedlingstein, P., Ciais, P., Sitch, S., and Prentice, I. C.: A dynamic global vegetation model for studies of the coupled atmosphere-biosphere system, Global Biogeochem. Cy., 19, GB1015, doi:10.1029/10532003GB002199, 2005.

Kuzyakov, Y., Friedel, J. K., and Stahr, K.: Review of mechanisms and quantification of priming effects, Soil Biol. Biochem., 32, 1485-1498, 2000.

Lavelle, P.: Faunal activities and soil processes: adaptive strategies that determine ecosystem function, Adv. Ecol. Res., 27, 93-132, 1997.

MEA: Millennium Ecosystem Assessment-Nutrient Cycling, World Resource Institute, Washington DC, 2005.

Mitchell, T. D., Carter, T. R., Jones, P. D., Hulme, M., and New, M.: A Comprehensive Set of High-Resolution Grids of Monthly Climate for Europe and the Globe: The Observed Record (19012000) and 16 Scenarios (2001-2100), Tyndall Center for Climate Change Research, University of East Anglia, Norwich, UK, 33 pp., 2004.

Moorhead, D. L. and Sinsabaugh, R. L.: A theoretical model of litter decay and microbial interaction, Ecol. Monographs, 76, 151174, 2006.

Myneni, R. B., Ramakrishna, R., Nemani, R., and Running, S. W.: Estimation of global leaf area index and absorbed par using radiative transfer models, IEEE Geosci. Remote Sens. Lett., 35, 1380-1393, 1997.

Ngo-Duc, T., Laval, K., Ramillien, G., Polcher, J., and Cazenave, A.: Validation of the land water storage simulated by Organising Carbon and Hydrology in Dynamic Ecosystems (ORCHIDEE) with Gravity Recovery and Climate Experiment (GRACE) data, Water Resour. Res., 43, W04427, doi:10.1029/2006WR004941, 2007.

Parton, W. J., Stewart, J. W. B., and Cole, C. V.: Dynamics of C, N, $\mathrm{P}$ and $\mathrm{S}$ in grassland soils - a model, Biogeochemistry, 5, 109131, 1988.

Phillips, R. P., Meier, I. C., Bernhardt, E. S., Grandy, A. S., Wickings, K., and Finzi, A. C.: Roots and fungi accelerate carbon and nitrogen cycling in forests exposed to elevated $\mathrm{CO}_{2}$, Ecol. Lett., 15, 1042-1049, 2012.

Piao, S. L., Friedlingstein, P., Ciais, P., Zhou, L., and Chen, A.: Effect of climate and $\mathrm{CO}_{2}$ changes on the greening of the Northern Hemisphere over the past two decades, Geophys. Res. Lett., 33, L23402, doi:10.1029/2006GL028205, 2006.

Piao, S. L., Ciais, P., Friedlingstein, P., Peylin, P., Reichstein, M., Luyssaert, S., Margolis, H., Fang, Y. J., Barr, A., Chen, A. P., Grelle, A., Hollinger, D. Y., Laurilia, T., Lindroth, A., Richardson, A. D., and Vesala, T.: Net carbon dioxide losses of northern ecosystems in response to autumn warming, Nature, 451, 49-53, 2008.

Post, W. M. and Kwon, K. C.: Soil carbon sequestration and landuse change: processes and potential, Glob. Change Biol. 6, 317327, 2000.

Proctor, M. E., Siddons, P. A., Jones, R. J. A., Bellamy, P. H., and Keay, C. E.: LandIS - a land information system for the UK. In: Land Information Systems: Developments for Planning the Sustainable Use of Land Resources, edited by: Heineke, H. J.,
Eckelmann, W., Thomasson, A. J., Jones, R. J. A., Montanarella, L., and Buckley, B., European Soil Bureau Research Report No 4, EUR 17729 (EN), Office for Official Publications of the European Communities, Luxembourg, 219-233, 1998.

Richardson, C. W. and Wright, D. A.: WGEN: a model for generating daily weather variables, US Department of Agriculture, Agricultural Research Service, ARS-8, 83 pp., 1984.

Robinson, R. A. and Sutherland, W. J.: Post-war changes in arable farming and biodiversity in Great Britain, J. Appl. Ecol., 39, 157176, 2002.

Rustad, L. E., Huntington, T. G., and Boone, R. D.: Controls on soil respiration: implications for climate change, Biogeochemistry, 48, 1-6, 2000.

Rustad, L., Campbell, J., Marion, G., Norby, R., Mitchell, M., Hartley, A., Cornelissen, J., and Gurevitch, J.: A meta-analysis of the response of soil respiration, net nitrogen mineralization, and aboveground plant growth to experimental ecosystem warming, Oecologia, 123, 543-562, 2006.

Santaren, D., Peylin, P., Viovy, N., and Ciais, P.: Optimizing a process-based ecosystem model with eddy-covariance flux measurements: A pine forest in southern France, Global Biogeochem. Cy., 21, GB2013, doi:10.1029/2006GB002834, 2007.

Schmidt, M. W. I., Torn, M. S., Abiven, S., Dittmar, T., Guggenberger, G., Janssens, I., Kleber, M., Kögel-Knabner, I., Lehmann, J., Manning, D. C., Nannipieri, P., Rasse, D. P., Weiner, S., and Trumbore, S. E.: Persistence of soil organic matter as an ecosystem property, Nature, 478, 49-56, 2011.

Shinozaki, K., Yoda, K., Hozumi, K., and Kira, T.: A quantitative analysis of the plant form: the pipe model theory, Japanese J. Ecol., 14, 98-104, 1964.

Sitch, S., Smith, B., Prentice, I. C., Arneth, A., Bondeau, A., Cramer, W., Kaplan, J.O., Levis, S., Lucht, W., Sykes, M. T., Thonicke, K., and Venevsky, S.: Evaluation of ecosystem dynamics, plant geography and terrestrial carbon cycling in the LPJ dynamic global vegetation model, Global Change Biol., 9, 161$185,2003$.

Six, J., Conant, R. T., Paul, E. A., and Paustian, K.: Stabilization mechanisms of soil organic matter: Implications for C-saturation of soils, Plant Soil, 241, 155-176, 2002.

Smith, P., Chapman, S. J., Scott, W. A., Black, H. I. J., Wattenbach, M., Milne, R., Campbell, C. D., Lilly, A., Ostle, N., Levy, P. E., Lumsdon, D. G., Millard, P., Towers, W., Zaehle, S., and Smith, J. U.: Climate change cannot be entirely responsible for soil carbon loss observed in England and Wales, 1978-2003, Glob. Change Biol., 13, 2605-2609, 2007.

Thoning, K. W., Tans, P. P., and Komhyr, W. D.: Atmospheric carbon- dioxide at Mauna Loa Observatory. 2. Analysis of the NOAA GMCC data, 1974-1985, J. Geophys. Res., 94, 85498565, 1989.

Todd-Brown, K. E. O., Randerson, J. T., Post, W. M., Hoffman, F. M., Tarnocai, C., Schuur, E. A. G., and Allison, S. D.: Causes of variation in soil carbon simulations from CMIP5 Earth system models and comparison with observations, Biogeosciences, 10, 1717-1736, doi:10.5194/bg-10-1717-2013, 2013.

von Lützow, M., Kögel-Knabner, I., Ekschmitt, K., Matzner, E., Guggenberger, G., Marschner, B., and Flessa, H.: Stabilization of organic matter in temperate soils: mechanisms and their relevance under different soil conditions - a review, European J. Soil Sci., 57, 426-445, 2006. 
Wutzler, T. and Reichstein, M.: Colimitation of decomposition by substrate and decomposers - a comparison of model formulations, Biogeosciences, 5, 749-759, doi:10.5194/bg-5-749-2008, 2008

Zaehle, S. and Friend, A. D.: Carbon and nitrogen cycle dynamics in the O-CN land surface model: 1. Model description, site-scale evaluation, and sensitivity to parameter estimates, Global Biogeochem. Cy., 24, GB1005, doi:10.1029/2009GB003521, 2010.
Zaehle, S., Sitch, S., Prentice, I. C., Liski, J., Cramer, W., Erhard, M., Hickler, T., and Smith, B.: The importance of age-related decline in forest NPP for modeling regional carbon balances, Ecol. Applications, 16, 1555-1574, 2006.

Zhou, L., Tucker, C. J., Kaufmann, R., Slayback, D., Shabanov, N., and Myneni, R.: Variations in northern vegetation activity inferred from satellite data of vegetation index during 1981 to 1999, J. Geophys. Res., 106, 20069-20083, 2001.

Zobler, L.: A World Soil File for Global Climate Modeling. Technical Mem- orandum 87802. NASA Goddard Institute for Space Studies (GISS), New York, NY, 1986. 